\title{
Technical and Vocational Education (TVE): Role in Individual and National Growth
}

\author{
Salma Amin \\ Research Scholar \\ Dr. B.A.M. University, \\ Aurangabad(MH), India.
}

\begin{abstract}
This paper focuses on understanding the role of Technical and Vocational Education (TVE) in individual development by gaining better employment and higher earnings. It further explores the relationship between Technical \& Vocational Education and the growth of national economy. Technical and Vocational Education is the form of education that consists of training all necessary skills required for profitable employment as well as acquisition of basic educational foundation. TVE enables the individual to gain all necessary skills and competencies for employability which affect the national growth and development
\end{abstract}

Keywords: technical \& vocational education, employment, skills, competency, development, economy, workforce, learning

\section{INTRODUCTION}

Skills and knowledge play vital role in economic growth and social development of any nation. In this competitive era, nations with higher and better levels of knowledge and skills will counter to all possible opportunities and challenges more efficiently and swiftly. In this era of globalisation, developing nations need to develop knowledge manpower who should be more analytical, adaptable and multi skilled. For developing a knowledge economy, the workforce of that nation should poses all necessary employability skill sets such as professional, managerial, operational, behavioural, inter personal and inter functional skills. To achieve this ambition, developing economies such as India need to develop a strong education system that will tender the foundation for learning and developing required employability skills and competencies.

Various studies have found that Technical and Vocational Education (TVE) plays a vital role in human resource development of the country by creating skilled manpower, enhancing industrial productivity and improving the quality of life. TVE is the education system that provides the necessary knowledge and skills for employment.

\section{Objectives}

- To explore the concept of Technical \& Vocational Education (TVE).

- To discuss the role of Technical \& Vocational Education (TVE) in employability.

\section{RESEARCH METHODOLOGY}

This study is descriptive in nature and explores the need, role and relevance of vocational education on employability. The research paper is entirely based on secondary data collected from Government websites of different ministries, organizations, research papers, journals and published reports.

\subsection{Technical and Vocational Education}

TVE can be defined as the education which prepares individuals for specific trades, crafts and careers at various levels in all spheres of life. TVE basically consists of practical courses through which individual gains skills and experience directly linked to a career in future. It helps individuals to be skilled to grab better employment opportunities.

\subsection{Role of TVE in Individual and National Development}

TVE or skills-based education has become most crucial in today's scenario where every employer is expecting from its new and old employees to have all the practical skills they need. In this age of globalization, different investors are looking towards the countries with rich readily employable 'human capital'. The TVE can bring education into closer relationship with productivity and employability of workforce. TVE is designed to train individuals for a vocation or a specialized occupation and hence it directly results in increased productivity and competitiveness of a country. (Cornford, 2005) ${ }^{1}$.

UNESCO has already sensed the seriousness of the need of knowledge and skilled workforce, hence Technical \& Vocational Education and Training (TVET), literacy and higher education, is one of three priority subsectors. Certainly, it is corresponding to its work to encourage inclusive and equitable quality education and lifelong learning opportunities for all. ${ }^{2}$

Oranu $(2009)^{3}$ has very strong point regarding TVE that, unlike the general education, vocational education is skilloriented and trains both the head and the hands. It is clearly understood that TVE can make people knowledgeable as well as skilled enough to get better employment. According to Yusuf $(2006)^{4}$, TVE is a form of education that aims to prepare individuals for employment in recognized occupations. This form of education provides the skills, knowledge and attitudes necessary for effective employment. Odogwu $(2005)^{5}$ describes vocational education as a type of education which lay emphasis on preparation and participation in a recognised occupation of social value. 


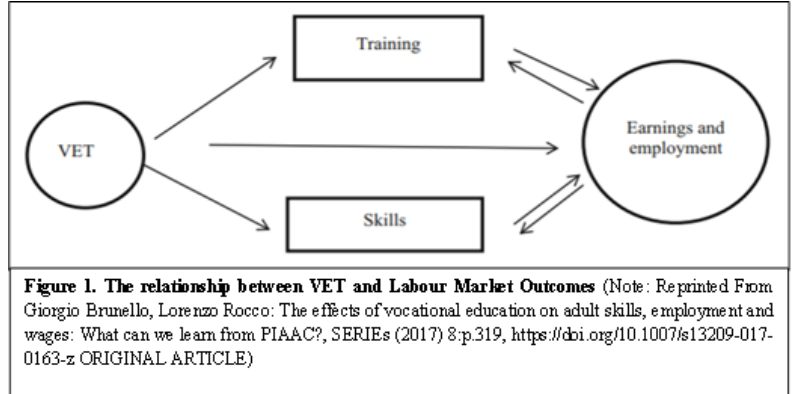

Giorgio Brunello and Lorenzo Rocco ${ }^{6}$ tried to explain the relevance between TVE and employment through a diagram i.e. Fig 1 . It is clearly observed that TVE has basic objective to provide training and skills to the individuals which enables them to get better employment and higher earnings.

Many other researchers have also highlighted the importance of TVE for the development of nations. Bishop and Mane $(2004)^{7}$, also in their study find that the students who opted vocational subjects in secondary school have very high chances of earning higher wages and exhibit higher participation rates as compared to general academic education students. Ryan $(2001)^{8}$, in his influential paper synthesised the cross-country evidence, showing that vocational programmes, especially apprenticeships, increase the chances of an early employment opportunity. Dearden et al. $(2002)^{9}$,in their study in UK, find that tough academic education produce higher returns, but also pointed out that the majority of vocational education programs increase earnings compared to nonvocational qualification, especially for low achieving school leavers. By this can be summarized that the TVE plays a vital role not only in developing countries but also in developed nations. Nuru (2007) ${ }^{10}$ in his study highlights that a nation's economy changes, it is necessary to prepare the youth for the future jobs and TVE has a very significant role in this process. TVE has a vital role of national development.

\subsection{Relationship between TVE and Workforce Demand \& Supply}

To add to the literature related to the role of TVE in growth of economy, Okafor and Emeka Christian ${ }^{11}$, in their study presented a model (Fig.2). In their Model Okafor and Emeka Christian describe that in developing country like Nigeria, TVE initiatives in core competency areas stimulate employment-orientations and competitiveness and boost socially and ecologically sustainable development practices. It can be summarized that the TVE focuses on core competencies which enables the workforce of a developing country to become more competitive. This model also states that most of the jobs are created by private sector where as only by TVE a country can produce sufficient skilled labour supply to meet the demand. TVE facilitate a developing and transition country to grow sustainably by creating ample of employment opportunities.

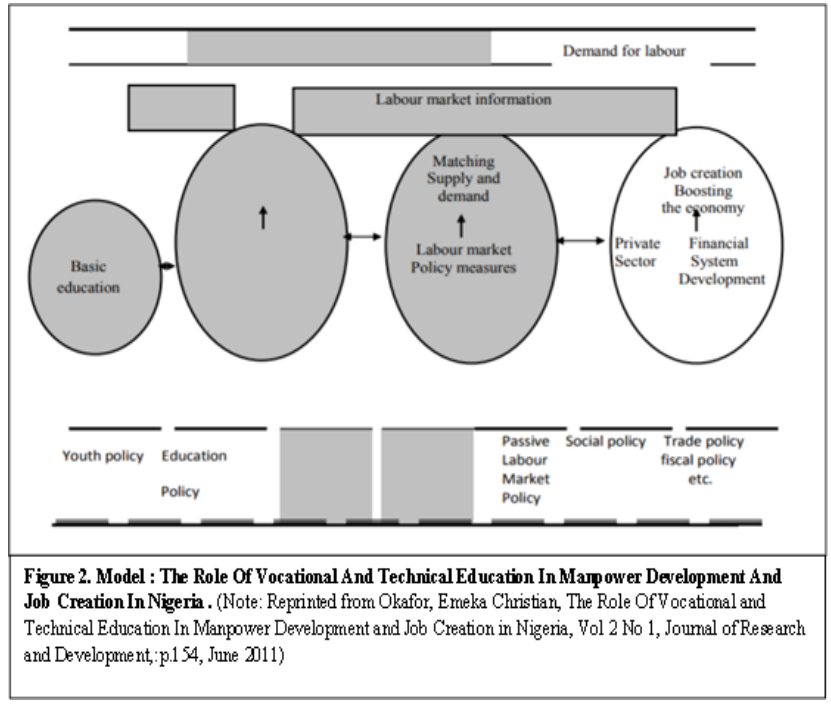

\section{CONCLUSION}

The role of TVE in facilitating social and economic growth has long been highlighted by many researchers. TVE plays a vital role in human resource development of the country by creating skilled manpower, enhancing industrial productivity and improving the quality of life. TVE is an education system with a vision to implant all necessary knowledge and skills to the individuals which enables them to get and retain on job. It can strengthen any country's employment which will further boost the economy of that country. A highly educated and skilled workforce will always foster the individual as well as national growth. By synthesising the findings of various studies carried out on TVE, it can be concluded that TVE plays very significant role in social equity and inclusion, as well as for the sustainability of development.

\section{REFERENCES}

[1] The benefits of vocational education and training, 2011.Luxembourg: Publications Office of the European Union.

[2] Vocational education. Retrieved from: https://en.wikipedia.org/wiki/Vocational_education

[3] Oranu k. 2009. Planning Industrial Technology Programmes in Universities of Technology, Issues in Curriculum Evaluation and Vocational Education in Nigeria. (Curriculum Organization of Nigeria, Monograph Series). Benin, Nigeria.

[4] Yusuf FR.2006 Issues and Challenges of Vocational and Practical Arts Education. New York: Unwin Publishers.

[5] Odogwu AC. 2005 An introduction to vocational and technical education In Nigerian schools and colleges. Owerri: Nigeria Wisdom People Publishers.

[6] Giorgio Brunello, Lorenzo Rocco. 2017 The effects of vocational education on adult skills, employment and wages: What can we learn from PIAAC?, SERIEs ,8:315-343, https://doi.org/10.1007/s13209-017-0163-Z ORIGINAL ARTICLE

[7] Bishop JH, Mane F. 2004 The impacts of careertechnical education on high school labour market success. Econ Educ Rev 23(4):381-402 
International Journal of Computer Applications Technology and Research

Volume 10-Issue 09, 213-215, 2021, ISSN:-2319-8656

[8] Ryan P. 2001 The school-to-work transition: a crossnational perspective. J Econ Lit 39(1):34-92.

[9] Dearden L, McIntosh S, Myck M et al. 2002 The returns to academic and vocational qualifications in Britain. Bull Econ Res 54(3):249-274.
[10] Nuru, A. 2007 The relevance of National Vocational Education Qualifications (NVQs) in TVE in Nigeria. unpublished conference paper.

[11] Okafor, Emeka Christian. June 2011 The Role Of Vocational and Technical Education In Manpower Development and Job Creation in Nigeria, Vol 2 No 1, Journal of Research and Development:152-153. 